\title{
WITOLD MARZĘDA
}

\section{DANIELA C. DENNETTA HIPOTEZA JĘZYKOWEJ GENEZY ŚWIADOMOŚCI}

Artykuł referuje strategię naturalizacji świadomości, której dokonał Daniel C. Dennett. Głównym założeniem tej naturalizacji jest przekonanie o językowej genezie świadomości. Zdaniem Dennetta - który w tym względzie kontynuuje myśl behawiorystów — świadomość jest ukrytym (sprywatyzowanym) zachowaniem językowym.

W artykule wskazuję, że takie ujęcie wiąże się z rozmaitymi trudnościami. Po pierwsze: jak pogodzić określanie świadomości jako sprywatyzowanego zachowania werbalnego z inną definicją, którą proponuje Dennett, głoszącą, że świadomość to wirtualna maszyna memetyczna? Po drugie: jak dana treść umysłowa może zostać uświadomiona oraz co różni treści świadome od innych treści umysłowych? Te zagadnienia prowadzą do najważniejszej kwestii poruszonej w artykule: jak teoria Dennetta - wbrew wielokrotnym deklaracjom samego autora - mogłaby zostać empirycznie sprawdzona? Argumentuję za tym, że koncepcja świadomości Dennetta nie podlega testom empirycznym.

Stary topos filozofii łączy myślenie i język. Platon w dialogu Sofista formułuje słynną metaforę: myślenie to „wewnętrzna rozmowa duszy samej z sobą, odbywająca się bez głosu" (263e 3-8; przekład Witwickiego). Arystoteles definiuje człowieka jako istotę żywą, która mówi, gdyż — jak zauważa Hans-Georg Gadamer - $\operatorname{logos}$ z arystotelejskiej definicji człowieka oznacza nie tylko rozum czy myślenie, lecz również język (GADAMER 2000, 52). Immanuel Kant w Antropologii wspomina o Indianach Othaiti, którzy myślenie nazywają mówieniem w brzuchu (KANT 2005, 105), a na

Dr Witold MarzęDA - Uniwersytet Śląski w Katowicach, Wydział Humanistyczny, Instytut Filozofii; adres do korespondencji: ul. Bankowa 11, 40-007 Katowice; e-mail: witold.marzeda@, us.edu.pl; ORCID: https://orcid.org/0000-0001-7516-3857. 
początku XX wieku w Badaniach logicznych Edmund Husserl pyta, czy mówiącemu do siebie „słowa służą za znaki własnych przeżyć?”, i natychmiast odpowiada, że byłoby to „zupełnie bezcelowe”, gdyż „wchodzące w grę akty są w tym samym momencie przeżywane" (Husserl 2000, t. 2 , cz. 1, 48).

W Dociekaniach filozoficznych Ludwig Wittgenstein formułuje problem inaczej: czy możliwy jest język, którego wyrazy odnosiłyby się tylko do prywatnych doznań mówiącego, czy możliwy jest język prywatny? Wittgenstein pisze:

Człowiek może dodawać sam sobie otuchy, sam sobie rozkazywać, samego siebie słuchać, karcić, karać, stawiać sobie pytania i odpowiadać na nie. Można by więc wyobrazić sobie ludzi mówiących tylko monologami. Czynnościom ich towarzyszy rozmowa z samym sobą. - Jakiś badacz, obserwując ich i przysłuchując się ich mowie, zdołałby może przełożyć ich język na nasz. (WitTGENSTeIN 2000,129)

W książce zatytułowanej Świadomość Daniel C. Dennett robi użytek z tej uwagi Wittgensteina, przedstawiając spekulatywną hipotezę: do powstania świadomości w toku ewolucji homini sapientis przyczynia się autostymulacja głosem, mówienie do siebie pod nieobecność partnera rozmowy. Autor pisze:

sugeruję, że w historii języka był moment, gdy wokalizacje służyły do uzyskiwania przydatnych informacji i dzielenia się nimi [...] aż pewnego pięknego dnia (tej racjonalnej rekonstrukcji) jeden z hominidów „przypadkowo” poprosił o pomoc, kiedy w zasięgu słuchu nie było żadnej pomocnej publiczności poza nim samym! (DeNNETT 2016, 274)

To był pierwszy kroczek na długiej drodze ewolucji świadomości.

Schemat ten pojawia się regularnie u Dennetta. W artykule „How to do Other Things with Words?” („Jak jeszcze inaczej działać słowami?”) autor szkicuje model akwizycji języka u dzieci:

Gorące - mówi mama - nie dotykaj pieca! Dziecko nie musi wiedzieć, co oznacza gorace, dotykać czy piec, słowa te są pierwotnie tylko dźwiękami, zdarzeniami słuchowymi [...] Zaczynają jednak wywoływać typ sytuacji-unikaniapieca, nie będąc już jedynie sytuacją, w której dany zakaz jest słyszany, lecz w której zawarta jest próba odtworzenia zjawiska słuchowego. W dużym uproszczeniu załóżmy, że dziecko nabiera nawyku mówienia do siebie: Gorące! Nie dotykać!, nie bardzo wiedząc, co znaczą te słowa, wymawiając je czasem jako skojarzenia z ćwiczeniem w rozpoznawaniu i unikaniu pieca i jako rodzaj mantry, którą można wygłaszać w dowolnym czasie. W końcu dziecko ma już nawyk powtarzania słyszanych słów, wypróbowywania ich w kontekście i poza nim, 
gromadzenia odsyłaczy i rozpoznawania ścieżek skojarzeniowych między własnościami słuchowymi a własnościami innych zmysłów i stanów wewnętrznych. [...] Ten proces może w efekcie prowadzić do nawyku, który można nazwać potowicznym-rozumieniem komentowania-siebie. (DenNetT 1997a, 221)

W Naturze umystów Dennett powtarza ten opis powstania świadomości: „bezmyślne praktyki - zwykłe wymawianie nazw - mogłoby przeobrazić się w nawyk reprezentowania sobie swoich własnych stanów i działań w nowy sposób" (DennetT 1997b, 171). Powrót od schematu dziecięcej akwizycji języka do obrazu jego ewolucji pojawia się z kolei w książce Od bakterii do Bacha. Widzimy tu pierwszych ludzi, podobnych gaworzącym dzieciom, którzy tylko czasem i nie do końca, a jednak powolutku, coraz częściej i lepiej się rozumieją. „Spekuluję - pisze Dennett - że był to stopniowy przyrostowy proces rosnących umiejętności, prowadzących do samokontroli, refleksji, pojawienia się nowych rzeczy, o których można myśleć: słów i innych memów w naszym obrazie manifestującym się" (DENNETT 2017b, 393).

Ontogeneza języka i świadomości, zdaniem Dennetta, nie różni się od filogenezy. W obu wypadkach to proces dwuetapowy. Najpierw bezmyślna paplanina (Tecumsech Fitch nazywa ten darwinowski scenariusz czystą fonologią - por. Fiтch 2005, 504) stabilizuje się i nabywa stałych znaczeń, a potem zostaje sprywatyzowana na użytek autostymulacji, która wytwarza życie świadome. Mówienie do siebie staje się (dziecięcym i ewolucyjnym) nawykiem, a potem cichnie: „Ten cichy proces podtrzymywałby pętlę autostymulacyjną, ale pozbyłby się peryferyjnej wokalizacji i słuchania. [...] Ta innowacja miałaby później kolejny zysk, oportunistycznie zaakceptowany, polegający na prywatności kognitywnej stymulacji” (DenNetT 2016, 276) ${ }^{1}$.

Dennett zdaje się nie przywiązywać większej wagi do opowiastki o hominidzie. Pokazuje ona, jego zdaniem zaledwie jedną z możliwości rozwinięcia się jednego $\mathrm{z}$ wielu możliwych nawyków. Opowiastka ta stanowi jednak prefigurację kluczowego elementu jego filozofii. Jest nim onto- i filogenetyczne warunkowanie świadomości przez język, prowadzące do wniosku, że świadomość jest ukrytym zachowaniem werbalnym ${ }^{2}$. Założenie to powtarza

${ }^{1}$ W Darwin's Dangeroeus Idea Dennett wskaże jeszcze jedną zaletę użycia języka możliwość operowania długimi ciągami myśli oraz zapamiętywanie i motywowanie siebie. Por. DENNETT 1995, 379 .

${ }^{2}$ Sprywatyzowany język autostymulacji u Dennetta nie posiada jednak prywatnego odniesienia. Co najwyżej prywatne zastosowanie publicznie korygowalnych odniesień. Jego referencji nie stanowią więc prywatne przeżycia. On te przeżycia stymuluje. Dlatego prywatyzacja języka nie pociąga tu za sobą sceptycznych zagadnień, znanych jako problem języka prywatnego. Por. MARZĘDA 2016, 61-78. 
behawiorystyczne teorie prywatnego użycia języka i odwraca tradycyjny sposób rozumienia relacji język-świadomość. To, co świadome, nie jest już, jak tradycyjnie przyjmowano, pierwotne i jako takie relacjonowane w języku. Dennett, za behawiorystami, uznaje, że komunikacja, mówienie o sobie i do siebie wywołuje świadomość.

Autor Dźwigni wyobraźni powtarza tym samym poglądy behawiorystów Georga W. Meada i Burrhusa F. Skinnera ${ }^{3}$ oraz kontynuatorów tej tradycji Juliana Jaynesa i Michaela Gazzanigi.

Georg W. Mead jest autorem ewolucyjnego scenariusza powstania umysłu i jaźni (ale nie świadomości!) ze sprywatyzowanego języka. Upatrywał on źródeł umysłu w komunikacji symbolicznej oraz przejmowaniu ról społecznych. Jako pierwszy opisał ów „stopniowy przyrostowy proces rosnących umiejętności, prowadzących do samokontroli, refleksji, pojawienia się nowych rzeczy, o których można myśleć". Początkiem komunikacji ma być, wedle Meada, gest wokalny, który jest - jak zauważa Charles Morris „właściwym źródłem języka i wszystkich pochodnych form symbolizmu; w tym także umysłu. Umysł jest bowiem występowaniem znaczących symboli w zachowaniu. Jest zdolnością wskazania sobie, co własna reakcja (oraz implikowane w niej obiekty) wskazuje innym i kontrolowaniem samych reakcji wedle tej zdolności" (Morris 1972, xx). Symbole to, według Meada, „«role innych», obiekty społeczne, które zakładamy, przewidując ich odpowiedzi, lub reakcje na nas samych" (KANG 1976, 119). Symbolem jest więc np. pytanie, które zakłada odpowiedź, a rozwijając pomysł Dennetta, należałoby powiedzieć, że paplanina przeradza się w język, gdy ustala się, różnicuje i rozszerza repertuar reakcji na określone wokalne zachowania.

Dla Meada symbol to „bodziec (stimulus), na którego odpowiedzi są ustanowione wprzód” (MeAD 1975, 181), jest gestem znaczącym, „za którego pomocą odnosimy się do tych jednostek, które są (lub sądzimy że są) funkcjonalnymi pośrednikami aktów społecznych" (ibid.). Umysł rodzi się z refleksyjności, połączonej z przejmowaniem roli, przy czym rola może być przyjmowana - dokładnie jak w spekulacji Dennetta — również wobec siebie. Dennett mógłby podpisać się pod tezą Meada:

[umysł] pojawia się tylko w społecznym postępowaniu ludzkich kręgowców. Stało się tak dlatego, bo jednostka odkryła, że sama przejmuje postawy innych, którzy są świadkami jej zachowania, i że staje się przedmiotem sama dla siebie.

\footnotetext{
${ }^{3}$ Dennett powołuje się na nich, krytykując hipotezę języka myśli Jerrego Fodora jako nieuprawnioną idealizację słusznej idei myślenia w języku. Por. Dennetr 1997a, 220.
} 
To zaś dzieje się tylko poprzez przejmowanie ról innych, od których znów możemy powrócić do samych siebie. (DenNetT 1997a, 283)

Burrhus F. Skinner wskazuje z kolei, że jednym z najistotniejszych elementów „magii słów” jest to, że energia wkładana w mowę bywa nieproporcjonalnie mała do siły otrzymywanego rezultatu oraz to, że zachowanie werbalne nie wymaga wsparcia ze strony środowiska. Można wszak wypowiedzieć słowo nie tylko pod nieobecność desygnatu, ale również pod nieobecność słuchacza. „Kolejną konsekwencją — pisze Skinner — jest to, że mówiący staje się również słuchającym i może zostać intensywnie wzmocniony przez własne zachowanie" (SKINNER 2013, 118). Zachowanie werbalne może opierać się także na opisie własnego działania:

[i]stotny repertuar językowy opisuje zachowania własne jednostki. Wytwarzany jest przez społeczność, która wymaga odpowiedzi na pytania jak: „Co powiedziałeś?”, „Co robisz?”, „Co zamierzasz zrobić?” czy „Dlaczego to robisz?”. Choć pytania te są zwykle praktyczne, równie ważne są ich teoretyczne implikacje. (SKINNER 1953, 262)

Dwie najważniejsze implikacje to fakt, że zarówno pytania, jak i odpowiedzi mogą zostać sprywatyzowane, oraz to, że nie wymagają obecności żadnego konkretnego środowiska.

Co więcej, zachowanie może pozostać ukryte, gdyż mówiący jest tu jednocześnie słuchającym i jego zachowanie werbalne może nieść prywatne konsekwencje. Skrytość formy tego zachowania jest również wzmacniana, nawet jeśli zostaje w ogromnej mierze zredukowana do niedostrzegalnych w środowisku skutków. (Ibid., 264)

Powstanie i wzmocnienie ukrytego zachowania werbalnego ma kilka źródeł. Jednym $\mathrm{z}$ nich jest rozszerzenie informacji o środowisku poprzez raportowanie danych, dostępnych tylko jednemu członkowi grupy, kolejnym - wzmacnianie nawyku raportowania samemu sobie pod nieobecność odbiorcy, a wreszcie raportowanie sobie, pod nieobecność desygnatu, które niesie „oportunistyczne zyski”, takie jak zdolność opracowywania złożonych problemów i zapamiętywania przez powtarzanie słów.

W ten sam sposób Dennett tłumaczy ludzką zdolność rozwiązywania problemów: „zadajemy samym sobie konkretne pytania, a praktyka ta nie ma łatwo wyobrażalnego odpowiednika wśród zwierząt nieposiadających języka" (Dennett 1997a, 232). Pozwala ona jednak, w uwewnętrznionym środo- 
wisku, reprezentować przedmioty pod ich nieobecność, a nawet stwarzać nowe obiekty. Dennett uważa, że właśnie w ten sposób można tłumaczyć nie tylko typowo ludzkie zdolności rozwiązywania problemów, lecz również powstanie świadomości.

Treści umysłowe stają się świadome nie dlatego, że dostają się do jakiejś specjalnej komory w mózgu [...], lecz dlatego, że wygrywają współzawodnictwo o kontrolę nad zachowaniem [...] I od kiedy potrafimy mówić, a mówienie do samych siebie jest jednym z najbardziej wpływowych działań, jakie wykonujemy, to najbardziej skutecznym sposobem — choć nie jedynym - na zdobycie wpływu przez treść umysłową jest przejęcie sterów nad elementami odpowiedzialnymi za mowę. (Dennett 1997a, 233).

Dennett bardzo niefrasobliwie traktuje rozróżnienie między świadomością a umysłem i jaźnią. W niektórych kontekstach terminy te mogłyby być stosowane wymiennie. Zgodnie z zasadą życzliwości należy jednak przyjąć, że mamy tu do czynienia $z$ trzema krokami. Po pierwsze, język, wedle scenariusza Meada, powołuje do życia wyjątkowy ludzki umysł: „słowa pisze Dennett - są narzędziami, które sprawiają, że jesteśmy bardziej inteligentni, ułatwiając poznanie w taki sam sposób (ale wielokrotnie spotęgowany), w jaki wskaźniki i punkty orientacyjne ułatwiają nawigację w otoczeniu prostszym stworzeniom” (DENNETT 1997b, 169), ponadto „pojawienie się języka [...] okazało się technologią, która stworzyła ogromną klasę nowych przedmiotów-do-rozważania, ucieleśnionych w słowie zastępników, które można przeglądać w dowolnym porządku i tempie" (DenNetT 1994, 165). A nawet więcej „to słowa są prototypami czy przodkami pojęć. Pierwsze pojęcia, jakimi potrafimy manipulować są «wysłowionymi» pojęciami" (Dennetr 1997b, 174). Po drugie, z czasem wśród pojęć pojawiają się pojęcia introspekcyjne, a wśród zachowań językowych pojawiają się zachowania ukryte. Ich połączenie prowadzi, jak wskazuje Skinner, do powstania świadomości, czyli prywatnego introspekcyjnego zachowania werbalnego. Po trzecie wreszcie, nawyki stosowania prywatnego języka, regularne raportowanie własnych stanów i przypisywanie ich innym wytwarzają jaźń.

Ta niefrasobliwość w stosunku do pojęć umysłu i świadomości pojawia się u Dennetta także przy memetycznej definicji świadomości. Głosi ona, że świadomość jest „sama w sobie ogromnym kompleksem memów (dokładniej mówiąc efektów memowych w mózgach), wirtualną maszyną przetwarzającą memy” (Dennett 2016, 295). Mem jest „sposobem zachowania (mniej więcej), który może być kopiowany, przekazywany, nauczany, odrzucany, 
wypowiadany, potępiany, wyśmiewany, parodiowany, ocenzurowany, uświęcony” (Dennett 2017b, 274). Do tego słowa „są najlepszymi przykładami memów" (ibid., 235). W połączeniu tych stwierdzeń świadomość okazuje się wirtualną maszyną (programem) do przetwarzania sposobów nieinstynktownego zachowania organizmu, przede wszystkim zachowania werbalnego. Świadomość w tej definicji jest właściwie synonimem umysłu, a przynajmniej ludzkiej umysłowości (wszak można powielać zachowania nieświadomie).

Niefrasobliwość tę widać wyraźnie również wtedy, gdy Dennett wskazuje inne źródło swoich inspiracji - koncepcję dwukomorowego umysłu. Przedstawia ją Julian Jaynes w słynnej pracy zatytułowanej Origins of Consciousness in a Brakedown of Bicameral Mind. W eseju poświęconym projektowi Jaynesa Dennett przyznaje, że wielokrotnie korzystał z jego idei, i że opiera się ona na ważnym, acz problematycznym założeniu:

Jeśli chcesz korzystać z ciekawego pomysłu, że świadomość pojawia się po wyłonieniu zbioru innych pojęć, musisz oczywiście przygotować swój konceptualny przybornik na obronę tezy, że pojęcia mogą być przed-świadome, że nie wymagają świadomości. Wielu utrzymywało, że nie ma czegoś takiego jak nieświadome posiadanie pojęć, lecz ujęcie źródeł świadomości u Jaynesa zależy od stwierdzenia, że wypracowanie schematu pojęciowego pod odpowiednią społeczną i środowiskową presją było warunkiem wstępnym pojawienia się takiej świadomości, jaką znamy. (DennetT 1998, 128)

Wynika stąd, że pojęcia (u Dennetta memy) mogą być przetwarzane przedświadomie. Jeśli tak, to właśnie umysł, a nie świadomość byłby maszyną przetwarzającą memy. Dopiero na pewnym etapie tego umysłowego przetwarzania pojawiłby się mem świadomości w postaci zespołu form językowych (np. metafor) pozwalających opisać życie wewnętrzne.

Jaynes, badając starożytne teksty, zauważa, że nie ma w nich jeszcze żadnych wzmianek na temat introspekcji ani metafor odniesienia do siebie. Język bohaterów spod Troi nie został jeszcze sprywatyzowany, ludzie ci więc nie są jeszcze świadomi. Zamiast tego słyszą głosy, które przypisują bogom, i czasem nawet widzą ich postaci. Jaynes pisze:

W odróżnieniu od nowych, subiektywnych, świadomych umysłów możemy uznać mentalność Mykeńczyków [tak Jaynes określa ludzi przedświadomych W.M.] umysłowością dwukomorową. Chcenie, planowanie, inicjatywa są organizowane tu zupełnie nieświadomie, a potem komunikowane jednostce $\mathrm{w}$ znanym jej języku wraz z cudowną aurą przyjaciela, postaci jakiegoś autorytetu, lub boga, a czasem po prostu jako sam głos. (JAYNES 2000, 75). 
Jaynes twierdzi, że te głosy u ludzi sprzed trzech tysięcy lat wytwarzane są w odseparowanej prawej półkuli i trafiają do ośrodków mowy w lewej półkuli, gdzie są dekodowane i słyszane jako obce. „Bogowie — pisze Jaynes - byli organizacjami centralnego systemu nerwowego i można rozumieć ich jako przejmujące zjawy osób pojawiających się w czasie, amalgamaty opiekuńczych lub ostrzegawczych obrazów" (ibid. 73). Około 1000 r. p.n.e. bogowie milkną. Pojawiają się, zdaniem Jaynesa, świadectwa językowe, pozwalające sądzić, że wykształciły się nowe sposoby relacjonowania świadomości za pomocą metafor.

Dennett podsumowuje:

pomysł Jaynesa jest taki, że na drodze do tego, czym jesteśmy teraz, musiała wydarzyć się rewolucja - prawie na pewno nie była ona organiczna, lecz była rewolucją oprogramowania - rewolucją $\mathrm{w}$ organizacji naszego systemu przetwarzania informacji i musiała wydarzyć się po języku. To, jak sądzę, zupełnie wspaniały pomysł i jeśli Jaynes myli się w szczegółach, to pal licho, lecz coś podobnego do tego, co opisuje Jaynes, po prostu musiało się wydarzyć. (DeNNETT 1998, 134)

Pomysł ten, jak zauważają Tim Baynes i Elisabeth Pacherie ${ }^{4}$, rozwija także Michael Gazzaniga (DENnetT 2016, 279). Hipoteza narracyjnie fingowanej jaźni Gazzanigi, na którego badania powołują się zarówno Jaynes, jak i Dennett, ma połączyć szereg eksperymentów i klinicznych obserwacji: od pomiarów różnic między aktywnością mózgu a świadomą decyzją (dokonanych przez Benjamina Liebeta), anasognozji reduplikacyjnej, fałszywej pamięci, po skutki rozszczepienia mózgu. Zdaniem Gazzanigi wszystkie one wskazują na to, że rola świadomości sprowadza się do tłumaczenia działań organizmu post factum:

Nie powinno dziwić, że nie zdajemy sobie sprawy z większości działań, w które zaangażowany jest mózg. Ta ogromna przestrzeń aktywności mózgowej jest miejscem, w którym robi się plany dotyczące mówienia, pisania, rzucania piłki lub zbierania naczyń ze stołu. Robimy to wszystko bezwiednie, nie mając pojęcia o tym, jak to działa i jak się sprawdza. Nie planujemy i nie artykułujemy tych działań. Po prostu oglądamy je na wyjściu. (Gazzaniga 1998, 114)

\footnotetext{
${ }^{4}$ „Rozważając przypadki rozszczepionego mózgu w świetle Dennettowskiej koncepcji dotyczącej roli narracji w interpretacji siebie, Rosner i Gazzaniga utrzymywali, że lewa półkula mózgu zawiera interpretatora, którego zadaniem jest nadawanie sensu własnemu zachowaniu podmiotu działającego" (BAYNES i PACHERIE 2006, 478).
} 
Celem narracyjnego sprawozdania jest „włączanie informacji w zrozumiałą całość" (ibid., 56). Interpretator komponuje wyjaśnienia działań organizmu oglądanych na wyjściu tak, aby stworzyć wrażenie, że działania te stanowią elementy integralnego planu.

Lewa półkula może być odpowiedzialna za poczucie, że nasze doświadczenie jest zintegrowane (unified). Generowanie wyjaśnień dotyczących percepcji, wspomnień działań oraz związków między nimi prowadzi do skonstruowania osobowej narracji, która łączy elementy świadomego doświadczenia w spójną całość. (Roser i GAZZANIGA 2004, 58)

Gazzaniga używa często terminu „automatyzm”, a Dennett metafory automatu. Strumień świadomości jest więc komentarzem własnego i cudzego automatycznego zachowania, bieżących wydarzeń, planów.

Rozwijając wątek automatyzmu, Dennett przedstawia świadomość (lub jaźń - autor nie jest tu jednoznaczny) za pomocą analogii do maszyny produkującej teksty. Maszyna ta, określana mianem maszyny joyce'owskiej, to „zbiór specjalistycznych obwodów mózgowych, które dzięki grupie nawyków wpojonych częściowo przez kulturę, a częściowo przez samoeksplorację współpracują ze sobą" (DENNETT 2016, 319). Maszyna produkuje narrację, która zastępuje (postulowane przez Jaynesa) głosy. Ogólna zasada działania maszyny jest analogiczna do procesu percepcji znanego jako model wielokrotnych szkiców. Podobnie jak w spostrzeganiu, gdzie „przeżywamy tylko wytwory wielu procesów interpretacji — będących w istocie procesami

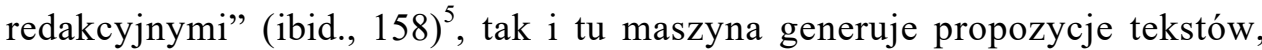
z których ostatecznie wypowiedziany jest (w samotnej mowie lub w konwersacji) jeden. Przy tym „nie istnieje żaden rygorystyczny podział na odgórne rozkazy co do treści, wypływające z głębi”; w związku z czym „musimy porzucić ideę, iż podmiot myśli zaczyna już od określonej myśli, która ma być wyrażona" (ibid., 338). Efektem działania maszyny produkującej strumień narracji jest złudzenie wirtualnego kapitana, szefa, jaźni, centralnego nadawacza sensu czy, jak kto woli, interfejsu użytkownika. Schemat pomysłu Jaynesa zostaje zachowany, zmienia się fabularny sposób jego prezentacji.

\footnotetext{
${ }^{5}$ Dalej Dennett opisuje model redagowania szkicu tak: „Przejmują one stosunkowo nieprzetworzone, jednostronne reprezentacje i dostarczają reprezentacji porównanych, skorygowanych i ulepszonych. Procesy te przebiegają w strumieniach aktywności w różnych miejscach w mózgu", lecz „wykrycie, czy rozpoznanie właściwości musi nastąpić tylko raz” (DenNETT 2016, 158).
} 
Analogia do maszyny joyce'owskiej, oprócz wskazania słynnej hipotezy jaźni jako narracyjnego środka ciężkości, ma jeszcze jedno ważne zadanie. Pokazuje automatyzm zachowania werbalnego. W eksperymencie myślowym opisanym w słynnym artykule „Jaźń jako narracyjny środek ciężkości” robot-pisarz nie tylko tworzy powieści, lecz posiada zdolność przemieszczania i wykazuje typowe językowe kompetencje w typowych sytuacjach: wita się, żegna, zaprasza, odmawia, opowiada o wczorajszych przygodach i planach na jutro, a zatrzasnąwszy się w łazience, wzywa pomocy. Takiej maszynie - Dennett nazywa ją Gilbertem - być może przypiszemy świadomość. To jednak nie jest konieczne.

Wciąż możemy twierdzić, że mózg robota, jego komputer naprawdę nie wie nic na temat świata; nie jest osobowością. To tylko rozklekotana maszyna. Nie wie, co robi. Nie wie nawet, że tworzy fikcyjną postać. (To samo dotyczy jednak twojego mózgu, on także nie wie, co robi). (DennetT 1994b, 108)

Analogia nie zamyka się więc $w$ językowych treściach generowanych przez mózg, lecz dotyczy też automatyzmu ich wytwarzania. Mówiący nie wie, skąd biorą się w nim słowa - ma instynkt mówienia.

Różnica między nami a schizofrenicznymi bohaterami Illiady (oraz społecznościami, które nie kładą nacisku na raporty introspekcyjne), polegałaby więc na tym, że nie słyszymy boskich głosów. Stymulujemy się głosami innych ludzi i własnym, a nasze strumienie świadomości opierają się na sprywatyzowanej narracji. Dramatyzm fantastycznej hipotezy Jaynesa (tysiące schizofreników oblega Troję) zostaje zredukowany do samotnego, beckettowskiego monologu. Żelazna zasada pozostaje jednak bez zmian. Dennett formułuje ją z właściwą sobie prostotą: „Bez mówienia do siebie nie można wiedzieć, co się myśli" (DennetT 2016, 444). To hipoteza językowej genezy świadomości. Zgodnie z nią świadomość zyskuje postać „wyciągu z działalności mózgu podanym w interfejsie języka" (DennetT 2017a, 263), a opowiastka o samotnym hominidzie, który sprywatyzował język, staje się prefiguracją jednego z najważniejszych rysów myślenia Dennetta o świadomości. Jak zauważa Peter Gärdenfors,

Dennett opisuje świadomość jako coś, co wyłoniło się z różnych, względnie niezależnych systemów znajdujących się w mózgu. Według niego systemy te nie mogą wytworzyć spójnej świadomości, dopóki nie rozwinie się mowa. Dzięki mówieniu do siebie, w wewnętrznym lub zewnętrznym monologu, powstają połączenia między poszczególnymi podsystemami i w ten sposób kształtuje się świadomość własnego ja. (GärdENFFrs 2010, 176) 
Umysł to aktywność poznawcza mózgu i ciała, którą wzmacnia i napędza język; świadomość natomiast jest przeżywaniem tego, że i co się mówi. Przeżycie świadome można więc określić jako stan lub działanie organizmu, które zostaje zrelacjonowane (co najmniej) w prywatnym języku: „błędem jest uważanie - napisze Dennett, powołując się na Elizabeth Ascombe - iż wiemy, jakie są nasze intencje: możemy powiedzieć, jakie są nasze intencje" (Dennetr 2016, 443). Świadomość nie jest obserwowana, lecz jest wypowiadana, jest w dużej mierze tym, co robią z nami słowa. Świadomy stan umysłu to taki stan, z którego podmiot może zdać sprawę w ukrytym bądź jawnym zachowaniu językowym. O czym nie można mówić, to zostaje poza świadomością.

Miejsce obcego głosu z rozważań Jaynesa zajmuje językowa autostymulacja oraz językowe formatowanie stanów mózgu. Dennett pisze, że

nie widzimy, nie słyszymy ani nie czujemy skomplikowanej maszynerii neuronowej pracującej w naszych mózgach, lecz musimy zadowolić się zinterpretowaną, skróconą wersją, złudzeniem użytkownika, które jest tak znajome, że uchodzi nie tylko za rzeczywistość, ale za najbardziej niepowątpiewalną i najbardziej znaną ze wszystkich rzeczywistość. Tak właśnie jest być nami. Poznajemy innych, słuchając lub czytając, co nam mówią. Tak też poznajemy samych siebie. (DeNnETT 2017a, 456)

$\mathrm{W}$ ten sposób mowa (i jej szczątkowa, uwewnętrzniona postać) udostępnia pracę mózgu, stając się treścią świadomości. Problem, który w XX wieku zaprzątał filozofów: czy możliwa jest świadomość bez języka?, znajduje prostą odpowiedź: nie. Język, w ukrytym zachowaniu werbalnym, wybiórczo formatuje prace mózgu, tworząc treść świadomości.

Koncepcja językowo stymulowanej świadomości nastręcza kilka interpretacyjnych trudności. Pierwsza to niespójność terminologiczna. U Dennetta jak wskazano - pojawiają się dwa ujęcia świadomości: jako ukrytego językowego zachowania oraz jako wirtualnej maszyny memetycznej. Świadomość rozumiana jako wirtualna maszyna do przetwarzania nieinstynktownych sposobów zachowania - memów - musiałaby istnieć, zanim pojawił się mem świadomości. Z koncepcji Dennetta wynika, że na Ziemi żyli ludzie, którzy byli świadomi, gdyż przetwarzali nieinstynktowne sposoby zachowania (memy) - rozpalali ogień, gotowali i uczyli potomstwo sporządzać narzędzia — i jednocześnie byli nieświadomi, gdyż nie posiadali w swoim językowym repertuarze wyrazów pozwalających na raportowanie przeżyć. Ta trudność 
wynika ze wskazanego wcześniej zamieszania pojęciowego i można ją rozwiązać, uznając maszynę memetyczną za synonim umysłu.

Zawirowanie pojęciowe na linii umysł-świadomość ma jednak poważniejsze konsekwencje. Nie wiadomo, czy to język tworzy typowo ludzką, świadomą umysłowość, a „nasz rodzaj myślenia musiał poczekać aż pojawi się mówienie" (DENNETT 1997b, 151), czy może zdolność komunikowania jest pewną miarą świadomej umysłowości, a zwierzęta posiadają świadomość proporcjonalnie do swoich biologicznych zdolności oznaczania i sygnalizowania (mrówki do chemicznego oznaczania szlków, ptaki i ssaki do wymiany sygnałów), czy może wreszcie język, jak chce Donald Davidson $^{6}$, stanowi warunek konieczny myślenia jako takiego? Dennett nie wskazuje, którą możliwość uznaje za słuszną.

Za każdym z tych rozstrzygnięć przemawiają pewne racje, lecz każde $\mathrm{z}$ nich niesie też pewne niewygodne konsekwencje. Jeśli na przykład uznamy zdolności sygnalizowania za miarę myślenia, to czy musimy uznać, że gen FOXP2 odpowiedzialny za wokalizacje może dzielić istoty na te posiadające biologiczne zalążki umysłu i te ich pozbawione? Czy chemiczna komunikacja komórek może wyznaczać granice pierwotnej świadomej umysłowości? Czy osoby z zespołem Williamsa oraz egotyczni poeci mają bardziej świadome umysły? Czy dzieci przed nabyciem języka nie są świadome? Ile różnych świadomości ma poliglota?

Kolejny, ważny kłopot na linii umysł-świadomość polega na tym, że nie wiadomo, wedle jakiej zasady dokonuje się w koncepcji Dennetta selekcja treści uświadomionych. Treści te nie są przygotowane wprzód do wypowiedzenia, lecz samo wypowiadanie czyni je świadomymi.

To z jednej strony rozwiązuje paradoks, na który zwraca uwagę Józef Bremer: „Dennett odrzuca «rzeczywistość» subiektywnych doświadczeń, chociaż równocześnie uznaje, że jedyny dostęp do ich treści mamy poprzez wypowiedź podmiotu" (BREMER 2005, 159). Z drugiej natomiast nie pozwala rozstrzygnąć, jak to się dzieje, że pewne informacje dostają się do świadomości (zostają wypowiedziane), a inne nie. Czy zależy to od gramatyki języka, poziomu jego opanowania, dostępnych środków wyrazu, presji używania danego języka w określny sposób, samych procesów neuronalnych, czy wszystkich tych czynników łącznie?

\footnotetext{
${ }^{6}$ „Bez przekonania nie ma innych postaw propozycjonalnych, nie ma więc racjonalności [...], aby posiadać przekonanie trzeba koniecznie posiadać pojęcie przekonania, aby posiadać pojęcie przekonania, trzeba posiadać język” (DAvidson 1992, 244.
} 
Zasada uświadamiania (tj. odsiewania treści) jest potrzebna Dennettowi, by odróżnić świadomość od umysłu i przeciwstawić się koncepcji, zakładającej, że świadomość poprzedza poznanie. Dennett w wielu rozdziałach książki Świadomość zmaga się z tym problemem, by ostatecznie zaproponować model wielogłosowy, w którym

istnieje rywalizacja między wieloma równoczesnymi zdarzeniami mózgowymi, a wybrany ich podzbiór „wygrywa”. [...] Niektóre z nich, łącząc siły z demonami językowymi, mają wpływ na wypowiedzi, zarówno te wypowiadane na głos do innych, jak i te ciche. (Dennett 2016, 386).

Zasadnicze pytanie pozostaje więc bez odpowiedzi. Zarówno walka o dostęp do demonów językowych, jak i integracja treści, które ten dostęp uzyskały, są rozstrzygalne, gdyż pewne treści... wygrywają. Jak zauważa w tym kontekście Józef Bremer: „Jeżeli Dennett chce wyjaśnić świadomość rozumianą, jako rodzaj, cechującego się jednością procesu, to musi umieć ponadto wyjaśnić, w jaki sposób postulowane przez niego procesy schodzą się razem" (2005, 171). Nie wiadomo jednak, dlaczego dany organizm powiedział to, a nie co innego (czyli nie wiadomo, jak powstaje interfejs pracy mózgu) i dlaczego w ogóle powiedziano (w ukrytej mowie) raczej coś niż nic.

Najważniejszy problem dotyczy jednak sprawdzalności teorii. Dennett chętnie wskazuje, że jego rozwiązania opierają się na etosie empirycznej skromności ${ }^{7}$. W Słodkich snach buduje opozycję między reakcjonistycznymi filozofami, którzy „otaczają świadomość uwielbieniem jako tajemnicę, wymykającą się nauce” (DENNETT 2005, 61), a badaczami, którzy „mogą wyjaśnić, czym jest świadomość równie głęboko i całkowicie, jak inne zjawiska naturalne: przemianę materii, reprodukcję, wędrówkę kontynentów, światło, grawitację itd." (ibid.). Reakcjoniści — Dennett nazywa ich też misterianami — „nie tylko uważają optymizm [w kwestii ewolucjonistyczno-mechanistycznego naturalizmu w wyjaśnieniu problemu umysłu] za słabo uzasadniony, lecz są też przekonani o jego nieuchronnej porażce" (ibid., 45).

Aby odróżnić się od misterian, autor Consciousness Explained nakłada na własną teorię mocne zobowiązania. Pisze, że w jego koncepcji „,[ż]adna

\footnotetext{
${ }^{7}$ Strategia skromnego empirysty jest jednym z siedmiu retorycznych zabiegów, jakie Dennett dzieli, zdaniem Anthony'ego Derksena, z Freudem. Okazuje się ona niezwykle opłacalna — choć $\mathrm{z}$ jednej strony narzuca pewne wymagania samemu autorowi, to z drugiej pozwala bez krytyki odrzucić wszelkie nieempiryczne koncepcje, ujmujące świadomość pierwszoosobowo. Por. DERKSEN 2005, 32.
} 
cudowna tkanka nie jest dozwolona”, i deklaruje, że postara się „wyjaśnić każdą niejasną właściwość ludzkiej świadomości, nie wykraczając poza współczesną fizykę” (DenNetT 2017b, 59) bez odniesienia do „niewyjaśnionych i nieznanych sił, substancji czy mocy organicznych” (ibid.). Nie próbuje jednak wskazywać dokładnego kryterium demarkacji. Z luźnych (i rozproszonych) uwag można wnioskować, że teorie misteriańskie to takie, które zarazem nie podlegają testom empirycznym i negują możliwość empirycznego wyjaśnienia problemu świadomości. Przy tym Dennett nie określa dokładnie, co rozumie przez empiryczną sprawdzalność. $Z$ tego względu nie można jednoznacznie rozstrzygnąć - mimo zapewnień samego autora - że jego koncepcje spełniają to kryterium. Sprowadzenie problemów świadomości do problemów języka (który stanowi przedmiot empirycznych testów) nie wystarcza, aby odróżnić koncepcje świadomości Dennetta od misterianizmu.

Dennett słusznie argumentuje, że — jak pokazują liczne badania wydolność funkcji umysłowych wzrasta znacząco dzięki językowi. Nie wynika stąd jednak, że można jakkolwiek empirycznie potwierdzić lub zaprzeczyć, że świadomość ma swoje źródła w języku. Powstanie języka jest faktem historii naturalnej. Darwinowska hipoteza pochodzenia języka z pieśni godowych, wsparta odkryciem efektu Baldwina (który tłumaczy przy okazji wpływ rozwoju języka na rozrost kory mózgowej) ${ }^{8}$, nie mówi nic o świadomości i nie jest jedyną wśród ewolucyjnych scenariuszy. Wiemy, że myślenie może być kształtowane (przynajmniej do pewnego stopnia) wedle struktury języka, pismo - co pokazuje Walter Ong — zmienia świadomość (ONG 2011), a techniki zapisu umożliwiły rozwój matematyki. Czy można jednak w ten sam sposób wyjaśniać świadomość? Czy jest ona jedną z funkcji umysłu, która pojawia się na linii przekształceń języka? Pozytywne odpowiedzi zależą od rozstrzygnięcia kwestii, jak miałyby przebiegać testy empiryczne tej hipotezy oraz które ze znanych badań mogłyby ją wspierać lub jej przeczyć.

Z koncepcji Dennetta wynika, że istnieli ludzie, którzy posiadali podobne do naszych funkcje poznawcze, lecz nie byli jeszcze świadomi. Czy można empirycznie sprawdzić tę hipotezę? Jakie znaleziska antropologiczne mogłyby ją sfalsyfikować lub potwierdzić?

\footnotetext{
${ }^{8}$ Terrence Deacon pisze, że „,największa strukturalna i funkcjonalna innowacja, która uczyniła ludzki mózg zdolnym do bezprecedensowych osiągnięć mentalnych, wyewoluowała w odpowiedzi na coś tak abstrakcyjnego i nienamacalnego, jak moc słowa [...] znaczące użycie symboli przez jakichś odległych przodków zmieniło sposób, w jaki naturalne procesy pobudzały ewolucję mózgu człowieka" (DEACON 1997, 322).
} 
Sam fakt, że istnienie nieświadomych ludzi daje się wpisać w historię rodzaju ludzkiego, nie czyni tego przypuszczenia empirycznie wartościowym. Załóżmy, że propozycja Dereka Bickertona (dziś powtarzana przez Daniela Everetta) (por. BicKerTon 1990, 122), głosząca, że homo erectus już półtora miliona lat temu posiadał pewien rodzaj deiktycznego języka, zostaje potwierdzona, załóżmy, że mamy pewność, iż był to język częściowo gestrualny, ze szczątkowym słownikiem intencjonalnym - czy to potwierdza, czy przeczy istnieniu nieświadomych hominidów?

Nie tylko w antropologii sprawa nie jest jednoznaczna. Krótkotrwałe lezje ośrodków mowy (wywołane przez czaszkową stymulacją magnetyczną lub silnym atakiem padaczki ${ }^{9}$ ) wskazują, że utrata mowy nie prowadzi do utraty świadomości. Za pomocą eyetrackingu wykazano, że goryle przechodzą tzw. test fałszywych przekonań, uznawany za kryterium możliwości symulowania stanu umysłów innych (KRUPENYE et. al. 2016, 110-114). Czy to obala hipotezę Dennetta?

Z kolei w starszych eksperymentach Michael Tomassello wykazał, że „proces nabywania umiejętności skonwencjonalizowanego użycia wytworów symbolicznych, a więc internalizacji owych sposobów konstruowania świata, radykalnie zmienia naturę poznawczych reprezentacji dziecka” (ToMASELlo 2002, 130). Czy to $\mathrm{z}$ kolei potwierdza ewolucyjną hipotezę powstania świadomości z pewnych użyć języka? Czy choćby pozwala stwierdzić, że dzieci w okresie nabywania języka są przed-świadome?

Sądzę, że nie można odpowiedzieć na te pytania. Z faktu, że język kształtował i napędzał umysłowość człowieka, po prostu nie wynika, że ukształtował świadomość. Niektórzy, jak Dieter Lohmar, argumentują, że język nie mógł wytworzyć nawet typowo ludzkiego myślenia, gdyż pół miliona lat temu ludzie musieli wykazać się niezwykłą przemyślnością w niegościnnych północnych rejonach Ziemi:

Wiedza o przydatności znajdowanego pokarmu [...] określaniu miejsc, w których można go znaleźć, ziół leczniczych, ocenianiu i leczeniu chorób itd. wymaga ekspertów, którzy muszą wykazać się dobrymi zdolnościami rozpoznawania i

\footnotetext{
${ }^{9}$ Brat John, kanadyjski mnich, jak opisuje Merlin Donald, cierpiał na napady padaczkowe, wywołujące silną afazję, która trwała nawet przez kilka godzin. W tym czasie porozumiewał się za pomocą nagranych na taśmie magnetofonowej prostych komunikatów i mimo że nie umiał wypowiadać słów (prywatnie i publicznie), bo ich nie pamiętał, nie zdradzał żadnych objawów nieświadomości. Por. Donald 1991, 89. Dennett odpiera ten zarzut dość zdawkowo: „brat John, jak i długotrwale niesłyszący ludzie nieużywający języka są na różne sposoby i w różnym stopniu, nadal beneficjentami kształtującej roli języka" (DENNETt, The Role of Language in Inteligence, 168.
} 
pamięcią, gdyż to od nich zależy przeżycie całej gromady. Inteligencja, wiedza, myślenie oparte na wyciąganiu wniosków i zdolność kooperacji stają się wiec najważniejsze dla utrzymania życia i wymagają systemów reprezentacji. Systemy te nie mogły jednak być oparte na języku, gdyż ten powstał najwcześniej 120000 lat temu. (LOHMAR 2016, 58)

Dennett sam nie wskazuje, jak jego teoria mogłaby zostać empirycznie sprawdzona. Fakt, że nie stoi ona w sprzeczności z nauką, nie czyni jej jeszcze naukową. Utożsamienie świadomości ze zdolnością raportowania jest bardzo użyteczne - wszak wiele badań opiera się na raportach werbalnych - i z pewnością bliskie jest potocznemu użyciu słowa świadomość. Jako arbitralne założenie nie rozstrzyga jednak statusu świadomości.

Naturalizacja świadomości u Dennetta polega na opracowaniu ważnego pytania: jakie rozumienie świadomości pozwala wpisać ją w pejzaż współczesnej nauki? Zadanie to Dennett wypełnia. Nie oznacza to, że daje odpowiedź na pytanie: czym jest świadomość? Ani: czy dysponujemy naukowym wyjaśnieniem świadomości? Daje, jako propozycję regulatywnego definiowania świadomości, instrumentalne podstawy empirycznych badań.

\section{BIBLIOGRAFIA}

BAyne, Thomas i Elisabeth PACHERIE. 2006. „Narrators and Comparators: The Architecture of Agentive Self-Awareness" vol. 159, no. 3: 475-491.

Bickerton, Derek. 1990. Language and Sepcies. Chicago: The University of Chicago Press.

Bremer, Józef. 2005. Jak to jest być świadomym? Analityczne teorie świadomości a problem umystu. Warszawa: Wydawnictwo IFiS PAN.

DAVIDSON, Donald. 1992. Eseje o prawdzie języku i umyśle. Red. Barbara Stanosz. Warszawa: Wydawnictwo Naukowe PWN.

DeAcon, Terrence W. 1997. The Symbolic Species. The Co-Evolution of Language and the Brain. London/New York: Norton \& Co.

Dennett, Daniel C. 1981. Brainstorms. Philosophical Essays on Mind and Psychology. Boston: The MIT Press.

Dennett, Daniel C. 1994a. „The Role of Language in Intelligence”. W: What is Intelligence?, red. Jean Khalfa, 161-178. Cambridge: Cambridge University Press.

Dennett, Daniel C. 1994b. „Self as a Center of Narrative Gravity”. W: Self and Consciousness: Multiple Perspectives, red. Frank S. Kessel, Pamela M. Cole, Dale L. Johnson, 103-115. Hilsdale/London: Lawrence Erlbaum Associates.

Dennett, Daniel C. 1995. Darwin's Dangeroeus Idea. Evolution and the Meanings of Mind. Boston: The MIT Press. 
Dennett, Daniel C. 1997a. „How to do Other Things with Words?” Royal Institute of Philosophy Supplements 42: 219-235.

Dennett, Daniel C. 1997b. Natura umystów. Tłum. Witold. Turopolski. Warszawa: Wydawnictwo CIS.

Dennett, Daniel C. 1998. Brainchildren. Essays on Designing Minds. Boston: The MIT Press.

Dennett, Daniel C. 2005. Stodkie sny. Filozoficzne przeszkody na drodze do nauki o świadomości. Tłum. Marcin Miłkowski. Warszawa: Wydawnictwo CIS.

Dennett, Daniel C. 2016. Świadomość. Tłum. Ewa Stokłosa. Kraków: Copernicus Center Press.

Dennett, Daniel C. 2017a. Dźwignie wyobraźni i inne narzędzia do myślenia. Tłum. Łukasz Kurek. Kraków: Copernicus Center Press.

Dennett, Daniel C. 2017b. Od bakterii do Bacha. O ewolucji umysłów. Tłum. Krystyna Bielecka i Marcin Miłkowski. Kraków: Copernicus Center Press.

Derksen, Anthony. 2005. „Dennett's Rhetorical Strategies in Consciousness Explained”. Journal for General Philosophy of Science / Zeitschrift für allgemeine Wissenschaftstheorie 36, no. 1: 29-48.

Donald, Merlin. 1991. Origins of the Modern Mind: Three Stages in the Evolution of Culture and Cognition. Cambridge: Harvard University Press.

FiтcH, Tecumsech. 2005. The Evolution of Language. Cambridge/New York: Cambridge University Press.

Gadamer, Hans-Georg. 2000. Rozum, stowo, dzieje. Tłum. Małgorzata Łukasiewicz i Krzysztof Michalski. Warszawa: PIW.

GäRdENFors, Peter 2010. Jak homo stat się sapiens? O ewolucji myślenia. Tłum. Tomasz Pańkowski. Warszawa: Wydawnictwo Czarna Owca.

GazzAniga, Michael. 1998. The Mind's Past. Oakland: University of California Press.

Husserl, Edmund. 2000. Badania logiczne. T. 2, cz. 1. Przełożył Janusz Sidorek. Seria: Biblioteka Klasyków Filozofii. Warszawa: Wydawnictwo Naukowe PWN.

JAYNES, Julian. 2000. The Origins of Consciousness in a Breakdown of Bicameral Mind. Boston/ New York: Houghton Mifflin Company.

Kang, Wi Jo. 1976. G. H. Mead's Concept of Rationality: A Study of the Use of Symbols and Other Implements. The Hague/Paris: Mouton.

KANT, Immanuel. 2005. Antropologia w ujęciu pragmatycznym. Tłum. Ewa Drzazgowska i Paulina Sosnowska. Warszawa: Wydawnictwo IFiS PAN.

Krupenye, Christofer, Fumihir Kano, Satoshi Hirata, Josep Call, Michael Tomassello. 2016. "Great apes anticipate that other individuals will act according to false beliefs". Science vol. 354: 110-114.

Lohmar, Dieter. 2016. Denken ohne Sprache. Phänomenologie des nicht-sprachlichen Denkens bei Mensch und Tiere im Licht der Evolutionsforschung, Primatologie, Neurologie. Seria: PHAE, vol. 219. Springer International Publishing Switzerland.

MARZĘDA, Witold. 2016. „Sceptyczne tropy Wittgensteina i transcendentalizm”. Folia Philosophica 36: 61-78.

MEAD, George H. Umyst, osobowość, społeczeństwo. Tłum. Zofia Wolińska. Warszawa: PWN, 1975.

Morris, Charles W. 1972. „Preface” do: George H. Mead. Mind, Self and Society: From a Standpoint of a Social Behaviorist. London/Chicago: University of Chicago Press. 
Ong, Walter J. Oralność i piśmienność. Słowo poddane technologii. Tłum. Józef Jopola. Warszawa: Wydawnictwa Uniwersytetu Warszawskiego, 2011.

Platon. 2000. Dialogi. T. 2. Przełożył Władysław Witwicki. Kęty: Antyk.

Roser, Mathew, i Michael Gazzaniga. 2004. „Automatic Brains - Interpretive Minds”. Current Directions In Psychological Science 4: 56-59.

Skinner, Barrus F. 2013. Behawioryzm. Tłum. Piotr Skawiński. Sopot: Gdańskie Wydawnictwo Psychologiczne.

SkinNer, Burrhus. F. 1953. Science and Human Behavior. New York: Free Press.

Tomasello, Michael. 2002. Kulturowe źródła ludzkiego poznawania. Tłum. Joanna Rączaszek. Warszawa: PIW.

Wittgenstein, Ludwig. 2000. Dociekania filozoficzne. Tłum. Bogusław Wolniewicz. Seria: Biblioteka Klasyków Filozofii. Warszawa: Wydawnictwo Naukowe PWN.

\section{DANIELA C. DENNETTA \\ HIPOTEZA JĘZYKOWEJ GENEZY ŚWIADOMOŚCI}

Streszczenie

Artykuł referuje poglądy amerykańskiego filozofa Daniela C. Dennetta, dotyczące językowego charakteru świadomości. W pierwszym kroku autor rekonstruuje Dennettowską strategię naturalizacji świadomości, pokazując, jak język umożliwia powstanie świadomości w toku ewolucji ludzi. Naturalizacja ta jest możliwa, wedle Dennetta, jedynie przy behawiorystycznym założeniu, zgodnie z którym świadomość jest ukrytym zachowaniem językowym. Autor pokazuje, jak Dennett przyswaja i przekształca pierwotne pomysły behawiorystów Meada, Skinnera i Jaynesa, wpisując je w ewolucyjny scenariusz. Inskrypcja ta prowadzi do konkretnych problemów, rozważanych w ostatniej części pracy: a) w filozofii Dennetta występują właściwie dwie definicje świadomości: pierwsza głosi, że świadomość jest pewnego rodzaju zachowaniem językowym, druga natomiast, że jest wirtualną maszyną memetyczną; b) Dennett nie wyjaśnia zasady rozstrzygalności, która pokazywałaby, jak dana treść umysłu może zostać uświadomiona, zamiast tego podaje tylko metaforę rywalizacji, w której pewne zdarzenia w mózgu (treści umysłowe) wygrywają z innymi; c) wpisanie możliwego scenariusza rozwoju świadomości w pejzaż ewolucji nie oznacza jeszcze, że teoria może zostać empirycznie sprawdzona.

Słowa kluczowe: świadomość; Daniel C. Dennett; język; behawioryzm; zachowanie językowe; empiryczna sprawdzalność.

\section{DANIEL C. DENNETT'S LANGUAGE OF CONSCIOUSNESS}

\section{Su m m a ry}

The paper discusses the lingual genesis of consciousness. The author reconstructs Daniel C. Dennett's naturalization strategy, showing how, according to Dennett, language enables the emergence of consciousness in the evolution of humankind. This naturalization assumes a behavioristic view according to which consciousness is a covert verbal behavior. The author shows that Dennett adopts and transforms Mead's, Skinner's, and Jaynes's original behavioristic approaches inscribing them into a course of human evolution. This inscription leads to specific problems discussed in the final part of the paper: 
There are actually two definitions of consciousness in Dennett's philosophy — first says that consciousness is a kind of verbal behavior, second says that it is a virtual memetic machine.

There is no explanation of the execution rule that could show how given mind content becomes conscious; Dennett introduces the competition metaphor instead. Some contentful events in the brain (mind contents) simply win with others. Inscription of the possible scenario of consciousness development in the evolutionary landscape does not mean that one can testify the theory yet.

Keywords: consciousness; Daniel C. Dennett; language; behaviorism; verbal behavior; empirical tests.

Information about the Author: Witold MARZĘDA, PhD — University of Silesia in Katowice, Faculty of Humanities, Institute of Philosophy; correspondence address: ul. Bankowa 11, 40-007 Katowice; e-mail: witold.marzeda@us.edu.pl; ORCID: https://orcid.org/0000-0001-7516-3857. 